\title{
伝熱実験における基板内熱伝導評価と熱流束の可視化*
}

\author{
功刀資 彰*1，秋野 詔 夫*1 \\ 一 宮 浩 市*2, 高 木 一 郎*3
}

\section{Evaluation of Heat Conduction and Visualization of Heat Flux in a Plate Making Use of Heat Transfer Experiments}

\author{
Tomoaki KUNUGI, Norio AKINO, \\ Koichi ICHIMIYA, and Ichiro TAKAGI
}

\begin{abstract}
This paper describes the evaluation method of heat conduction and visualization of local heat flux in a heated plate. In the first stage, the temperature distribution of the hated plate was measured in detail by the 'thermocamera' which we developed, using liquid crystal with high resolution $\left(0.01^{\circ} \mathrm{C}\right)$. In the next stage, the deviated heat flux in the plate was evaluated by solving numerically the three -dimensional equation of heat conduction. As a result, the heat flux distribution was visualized locally.
\end{abstract}

Key Words : Thermal Engineering, Heat Transfer, Heat Conduction, Liquid Crystal, Numerical Analysis, Heat Flux Visualization

\section{1. 緒}

対流伝熱実験を行う場合, 伝熱面に一様熱流束加熱 などの熱的境界条件を設定することが多い.このよう な熱的境界条件を設定する際には伝熱面を構成する基 板内の熱伝導量の定量的な評価が重要となる．伝熱促 進体などの突起物を伝熱面に設置した場合, 突起物自 身およびその周辺の熱伝達，温度，熱流束は伝熱面基 板内の熱伝導の影響を受ける。この影響は低レイノル ズ数の流れや自然対流などの熱流束が比較的小さい条 件で大きく現れる。これは熱伝導と熱伝達の結合問題 であるが，基板内熱伝導量の定量的評価がないため， 適切な実験デー夕処理法も確立されておらず，ほとん どの場合基板の厚さを無視した一次元熱伝導補正が適 用されている。しかし，突起物の寸法が小さい場合な ど必ずしも厚さが無視できない場合も多い。また，伝 熱促進の実験では，促進体要素からの伝熱量が必要と なるが，直接計測する方法はない，一方，著者らは「伝 熱の可視化」の有力な手段である感温液晶を用いた温

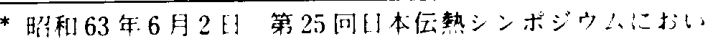
三講演, 原稿受付 平成元华 9 月2 2 月。

*1 日本原f少研究所（也319-11 茨城県那和郡東海村）。

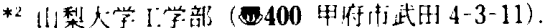

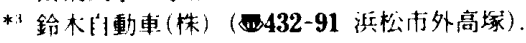

度分布の可視化法を用いて原子炉の燃料棒のスペーサ リブなどの伝熱流動に与える効果を研究してき た ${ }^{(1)-(3)}$. 最近, 著者らは液晶による温度分布の可視化 法を改良し，赤外線カメラに匹敵する簡便で高精度な 測定システムである「液晶サーモカメラ」の開発に成 功した ${ }^{(4)}$. 本方法の特徵は，液晶で可視化された色分 布を極めて多量(テレビの空間分解能＝数十万点)の温 度に変換して計測・画像表示でき，また極めて高い温 度分解能 $\left(0.01^{\circ} \mathrm{C}\right)$ を有することができる。

本報は，この液晶サーモカメラを用いて伝熱面上の 温度分布を周密に計測し，これを境界条件として基板 内の熱伝導方程式を解くことにより，基板内熱伝導量 の評価と種々の補正方法の定量的検討を行ったもので ある. 結果として三次元の偏差熱流束分布が得られ， 熱流束の可視化が可能となった。また，設定した熱流 束分布と偏差熱流束分布を積算することによって伝熱 面に取付けた促進体要素からの伝熱量の評価が可能に なった。 主要な記号の説明

$$
\begin{aligned}
H & : \text { 流路間隔 } \\
q & : \text { 熱流束 } \\
Q & : \text { 熱量 } \\
R e & : \text { レイルズ数 }
\end{aligned}
$$


$T:$ 温度

$U:$ 流路断面平均流速

\section{2. 液晶サーモカメラ}

温度測定に使用される液晶は, 主にコレステリック 系の液晶である。これは，鎖状分子が平行に配列して いる首状構造であり，各層間で分子軸の方向に角度の ずれを有し，全体としてへリカルな構造となってい る.このへリカルのピッチが可視光の波長の程度であ るため, 選択光散乱現象が生じ美しい「色」を呈する。 このピッチが温度により変化するので色と温度の関係 が定まることになる，液晶サーモカメラに関する詳細 は文献 ( 4 )に讓り,ここでは, その概要を述べる.

液晶サーモカメラでは温度 $T$ の液晶からの散乱反 射光を色分解光学フィルタで三つの色成分に分解して 色成分輝度を測定し，つぎの一次回帰式によって温度 予測值 $T^{*}$ を求めることができる.

$$
\begin{aligned}
& T^{*}=\alpha+\beta r+\gamma g+\delta b \\
& \quad+O\left(r^{2}, g^{2}, b^{2}\right) \cdots \cdots
\end{aligned}
$$

ここで， $\alpha, \beta, \gamma, \delta$ は定数である. $r, g, b$ は色成分輝 度比であり,ビデオカメラの出力信号は A-D 変換し た 8 bit の $\mathrm{R}, \mathrm{G}, \mathrm{B}$ 輝度值として得られるので, 総和 を $\mathrm{S}=\mathrm{R}+\mathrm{B}+\mathrm{G}$, バックグラウンドを $\mathrm{BG}$ として次式 で定義した。

$$
\begin{aligned}
& r=(\mathrm{R}-\mathrm{BG}) / \mathrm{S}, g=(\mathrm{G}-\mathrm{BG}) / \mathrm{S}, \\
& b=(\mathrm{B}-\mathrm{BG}) / \mathrm{S} \cdots \cdots \cdots \cdots \cdots \cdots \cdots \cdots \cdots \cdots \cdots \cdots \cdots
\end{aligned}
$$

また, 重回㷌式への当てはめ計算は, 最小二乗法に 基づき, 正規方程式を Gauss-Jordan 法で解き, 定数 $\alpha, \beta, \gamma, \delta$ を校正実験の镜測值 (熱電対の指示値) $T$ との最大誤差が許容值 (本実検では $0.2^{\circ} \mathrm{C}$ ) 内になるよ うに求めた。なお， $O\left(r^{2}, g^{2}, b^{2}\right)$ は残差項である。本

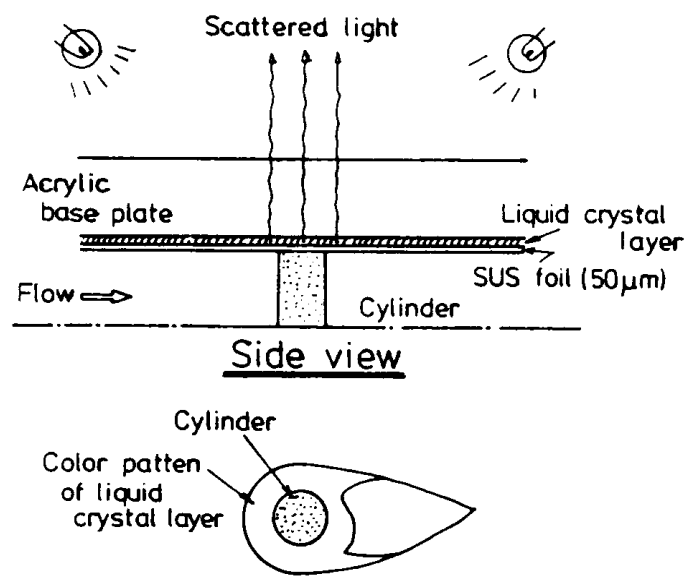

Elevation view

図 1 試験部の概要
実験で得られた定数は， $\alpha=25.98, \beta=4.36244, \gamma=$ $5.78944 ， \delta=11.3555$ 5゙ある.

この結果, $27^{\circ} \mathrm{C}$ 施 $31^{\circ} \mathrm{C}$ 温度範囲で $\pm 0.2^{\circ} \mathrm{C}$ 程度 の精度扔よび $0.01^{\circ} \mathrm{C}$ 分解能で測定が可能になった。

\section{3. 伝熱实験}

对流伝熱実験の一例として，原子炉燃料棒の伝熱面 上に存在するスペーサリブ周辺の熱伝達実験を取り上 げる. 本実験は，一般の伝熱促進体の効果を調べる実 験と基本的に同一である。実験装置の概要を示すと， 試験部は長さ $2100 \mathrm{~mm}$, 幅 $230 \mathrm{~mm}$, 流路間隔 10 $\mathrm{mm}$ のアクリル製平行平板流路であり，作動流体とし ては空気を用いた。加熱区間(長さ：750 mm)の流路 上板は図 1 に示すように，流体と接する側より抵抗発

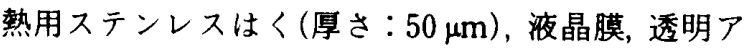
クリル板で構成されている，実験は，直径 $20 \mathrm{~mm}$, 高 さ $10 \mathrm{~mm}$ の真ちゅう製円柱 1 個を，流路中央に円形 面を流路壁に密着させて行った，流れ場の条件として は，低レイノルズ数の場合に基板内熱伝導が伝熱量の 評価に大きく影響を与えることを考慮し，流路間隔 $H$ の 2 倍を基準としたレイノルズ数 $\operatorname{Re}(=2 U \cdot H / \nu)=$ 1000 を取り上げた。液晶の発色画像は流路上面のアク リル板の上方から液晶サーモカメラで取り込み，画像 処理し，色分布を温度分布に変換した。伝熱面上に出 現した色分布のうち，円柱を含んだ周辺 $270 \times 88.8$ $\mathrm{mm}$ の長方形の領域が 16000 画素 $(200 \times 80: 1$ 画素 の寸法は $1.35 \mathrm{~mm} \times 1.11 \mathrm{~mm}$ )に分割された色成分輝 度值の画像デー夕 $(\mathrm{R} \cdot \mathrm{G} \cdot \mathrm{B}$ 各 8 bit で合計 48000 個の デー夕)として得られ，式(1)の温度変換式から16000 点の二次元温度分布が得られた。このときの等温線図

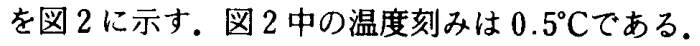

\section{4. 熱伝算補正法の検讨}

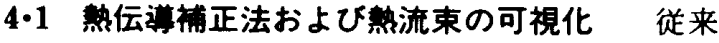
の基板内熱伝導量の評価は，ほとんどの場合基板の厚 さを無視した一次元熱伝導補正が適用されている。し かし，本液晶サーモカメラにより伝熱面の周密な二次 元温度分布(16 000 点)が得られたので, これを基板の

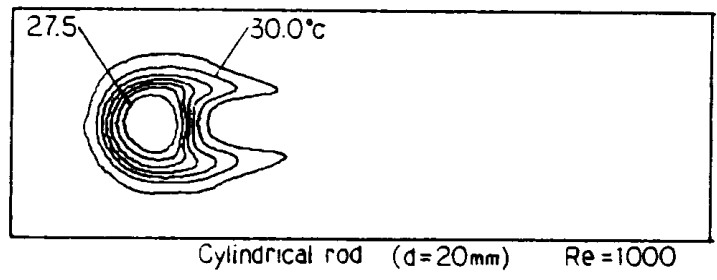

図 2 等温分布 
伝熱面側の境界条件として, 基板内部の三次元温度分 布を熱伝余数值解析により求め, 基板内の熱移動量を 評価した。また，ヒータであるステンレスはく内での 熱移動量も評価した.座標系と境界条件を図 3 に示す. 観察面側の流路上面が座標の原点である。

基板内の熱伝導方程式は, 発熱がないので次のラプ ラス方程式で記述され, 通常の有限差分法で温度分布 が求められる。

$$
\nabla^{2} T=0
$$

境界条件として，伝熱面には液晶温度計測で得られた 16000 点の温度分布を与え，伝熱面以外の基板の側面 には断熱条件を与えた。得られた基板内の温度分布か ら基板内を移動する熱流束分布 $q_{A}$ を求めた。

また,ステンレスはくは非常に薄く液晶膜と密着し ており, 液晶温度計測から得られた温度がステンレス はくの温度を示していると考えられる.したがってス テンレスはくを計測点に対応した 16000 個の微小要 素(ステンレスはくの厚さは一定)で置き換え，計測し た温度分布における二次元 $(x-y)$ ステンレスはくの微 小要素を通過する熱量 $Q_{s}$ の移動を次の保存式から評 価した。

$$
\operatorname{div}\left(Q_{s}\right)=0
$$

ここで, $Q_{s}=q_{s} \delta_{s}, q_{s}$ ははく内の局所熱流束, $\delta_{s}$ はは く内の厚さである.

液晶温度計測から得られた温度分布は分解能

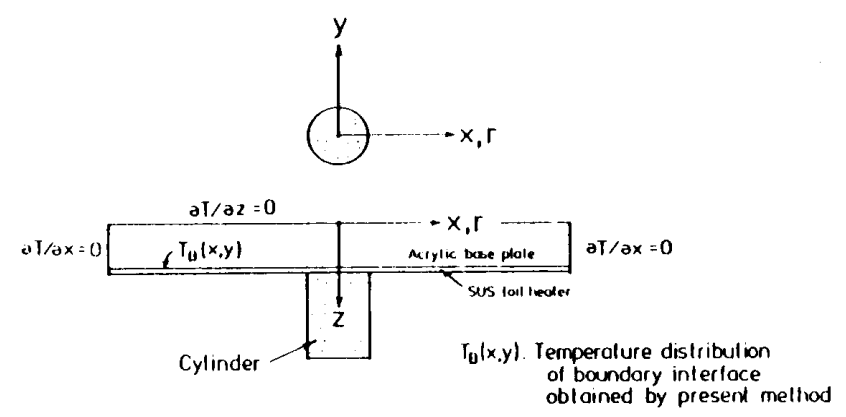

図 3 座標系と境界条件

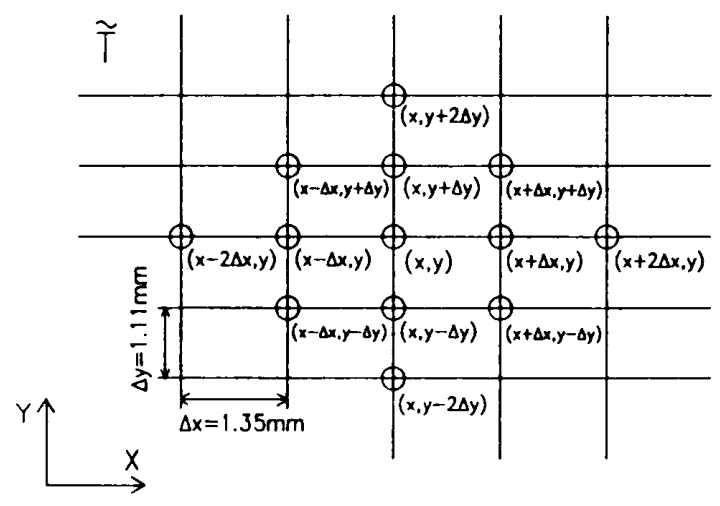

図 4 格子点 $\left(0.01^{\circ} \mathrm{C}\right)$ 以下のばらつきを有しており, 上式の $q_{s} を$ 評価するうえではこのばらつきが非現実的な振動を示 した。したがって実際には着目点 $(x, y)$ の温度は図 4 に示すような周囲 13 点から最小二乗法で求めた温度 $T$ ' と計測温度 $T$ との差 $\Delta T$ から温度勾配を評価し, $q_{s}$ および $Q_{s}$ を求めた。

図 5 は基板内三次元温度分布より求めた基板内から 伝熱面への熱流束の分布(これを印加した一様熱流束 条件からの偏りと考え，「偏差熱流束」と呼ぶことにす る)を示す。一様熱流束条件にもかかわらず伝熱面上の 局所的な温度分布のために基板内部に温度分布が生 じ, 結果として偏差熱流束が発生し, 高温部分から低 温部分へ熱が流れ込んでいる様子がわかる. 図 5 は熱 流束が可視化されたものである. 補正手法の検討の際 の副次的な結果であるが, 熱流束の可視化は「伝熱の 可視化」の中でも極めて例の少ないものであり，その 意味で本手法は画期的なものと言えよう.

$4 \cdot 2$ 各種熱伝荋補正法の検封本実験の体系の 熱伝導補正法には, 一次元, 二次元, 三次元の方法が ある. 座標系と境界条件は図 3 と同様である. 一次元 手法は多くの伝熱実験で行われている簡便な手法であ り，測定された伝熱面温度分布の一次元方向の温度こ う配から偏差熱流束を算出する方法であるため, 基板 内の熱移動量の評価はされない，二次元手法は伝熱面 温度分布を境界条件として基板内の熱移動量をパーソ ナルコンピュータなどで数值計算して偏差熱流束を求 める手法である. 本系の場合, 座標系間の相違を調べ るため直交座標 $(x-y)$ と円筒座標 $(r-z)$ の 2 とおりの 補正を行った。最後に, 三次元手法は上述の「熱流束の 可視化」で説明した手法である。計算は大形計算機で 行い, 基板方向 $(z)$ の格子分割数に依存するが, 約 8 MB 程度の容量と SOR 法による計算で約 $20 \mathrm{~min}$ 程 度の計算時間を要した。図 6 は，各補正法間の偏差熱 流束の見積もりの相違を示したもので，流れの入口か ら円柱までの流路上面の中心線上の分布である. 一次 元補正は温度こう配が急峻なところで過大な值を示し ている. 二次元の場合, 座標系間の相違は本実験では それほど大きくなかったが, 円柱上流側約 $25 \mathrm{~mm} の$

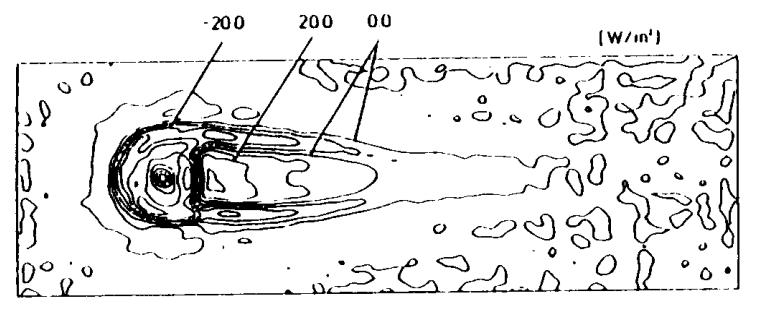

図 5 偏差熱流束分布 


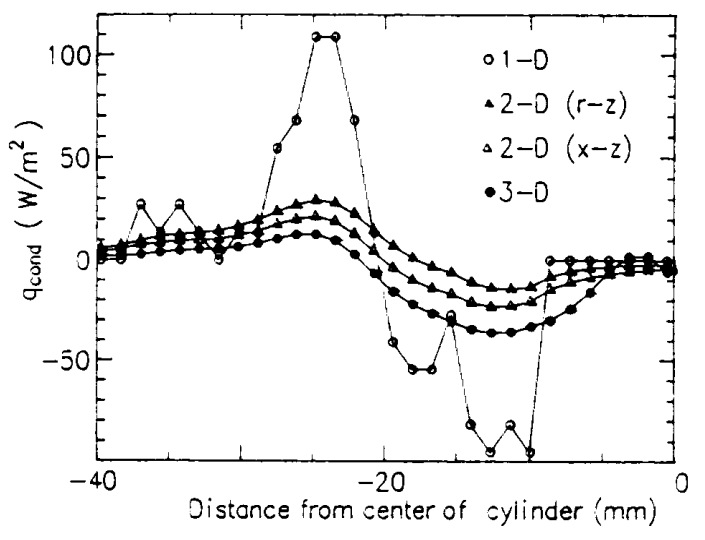

図 6 各補正間の比較

位置で三次元計算による補正量の約 2 倍, 約 $15 \mathrm{~mm}$ の位置で約 $1 / 2$ の值を示した。

次に, 本実験の基板厚さは $10 \mathrm{~mm}$ であり,上述の 補正計算はすべてこの寸法で行ったが，基板の厚さの 効果を調べるため，基板の厚さを仮想的に調べた。た だし，伝熱面側の温度は同一とした。図 7 は，偏差熱流 束の最大值の変化を示す。一次元補正は基板厚さを考 虑していないので実線のように一定のこう配を持つ。 二・三次元補正では基板厚さが増加するに従って偏差 熱流束も增加するが, $5 \mathrm{~mm}$ 以上ではほほ同一の值を 示しており無限厚さとみなせることがわかった。また, 基板を $1 \mathrm{~mm}$ 程度の厚さとしなければ一次元補正法 は使えないことがわかった。最後に，ステンレスは熱 伝導率が大きいので，はく内部の熱移動量の検討を行 った、この量の評価はステンレスはくを二次元平板と 仮定し，測定した温度分布を用いて温度点を含む微小 要素についての熱伝導方程式を全点で解き，偏差熱流 束を求めた。

したがって，伝熱面で考慮すべき熱流束は，抵抗加 熱による熱流束(設定值)と式 (3)より求められる基板 内および式(4)より求められるステンレスはく内を移 動する熱量より得られる偏差熱流束との総和というこ

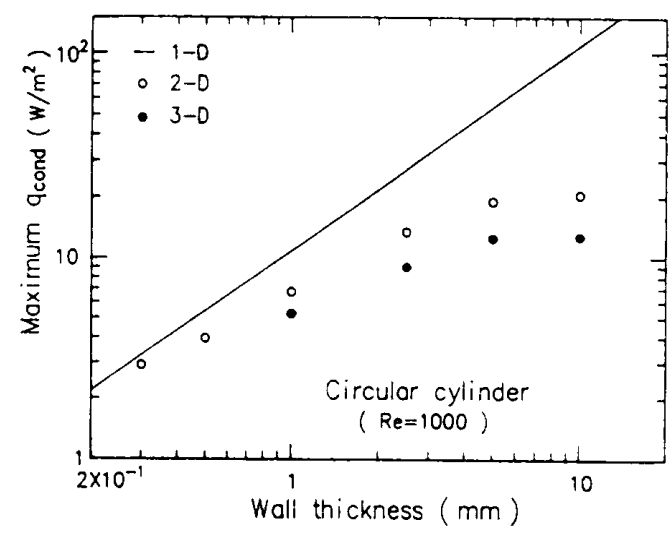

図 7 最大偏差熱流束

とになる、ちなみに，全発熱量 $12 \mathrm{~W}$ (一様熱流束条 件: $\left.69.6 \mathrm{~W} / \mathrm{m}^{2}\right)$ の場合，一様熱流束条件から決まる 促進体要素への入熱量は $0.0219 \mathrm{~W}$,アクリル製基板 内移動熱量は $0.013 \mathrm{~W}$ ，ステンレスはく内移動熱量は $0.00684 \mathrm{~W}$ であった.この量をすべて評価することに より伝熱面に取付けた促進体要素からの伝熱量の評価 が可能となった。

\section{5. 結埨}

流路内に伝熱促進体が設置された場合を対象に，伝 熱面基板内の熱伝導の影響を定量的に求めた。液晶サ 一モカメラを使用して伝熱面温度分布を詳細に計測 し，それを境界条件にして熱伝導方程式を解くことに より熱流束の可視化が得られた。また伝熱促進体要素 からの伝熱量の評価も可能となった。

\section{文献}

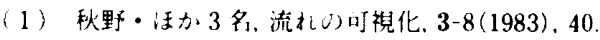

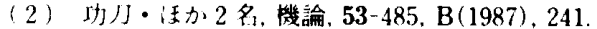

(3) Ichimiya, K.. 结か 3 多. Int. J. Heat Mass Transf.. 31$11(1988), 2215$.

(4) Akino, N.. 汪执 3 多, Trans. ASME. Ser. C. 111 $2\{1989\}, 558$. 